\title{
Localized Fibrous Tumors of the Pleura: Experience With 7 Recent Cases
}

\author{
W. Torre, ${ }^{a}$ N. Rodríguez-Spiteri, ${ }^{a}$ J.J. Sola, ${ }^{b}$ and M. Delgado ${ }^{a}$ \\ ${ }^{a}$ Departamento de Cirugía Torácica, Clínica Universitaria de Navarra, Pamplona, Navarra, Spain. \\ bDepartamento de Anatomía Patológica, Clínica Universitaria de Navarra, Pamplona, Navarra, Spain.
}

OвJECTIVE: Localized fibrous tumors of the pleura are rare. We report 7 cases and review the literature in order to define the range of clinical characteristics of these tumors, treatment options, and prognosis.

METHODS: A retrospective review of 7 cases treated between 1997 and 2003, focusing on clinical presentation, diagnostic tests, and treatment. The tumor was removed surgically in all cases, by thoracotomy in 6 cases and by video-assisted thoracoscopic surgery in 1 patient.

RESULTS: All patients recovered fully after surgery, with no postoperative complications. One patient experienced recurrence twice, 33 and 67 months after the initial resection. All are alive at the time of writing, after a mean follow up period of 19 months (range 1 month to 5 years and 10 months).

Conclusions: The treatment of choice for a fibrous tumor of the pleura is full resection and follow up to detect possible late recurrence.

Key words: Pleural neoplasm. Solitary fibrous tumor. Pleura.
Mesotelioma fibroso localizado de pleura: nuestra experiencia quirúrgica en 7 casos recientes

OвJETIVo: El tumor fibroso localizado de pleura es una lesión poco frecuente. El objetivo de este artículo es presentar 7 casos propios y revisar la bibliografía existente, con el fin de establecer el espectro clínico de estos tumores, el tratamiento y su pronóstico.

MÉTodos: Revisión retrospectiva de una serie de 7 casos intervenidos entre 1997 y 2003, analizando el modo de presentación, las pruebas diagnósticas y el tratamiento. En todos los casos se realizó una resección quirúrgica de la masa, que se llevó a cabo por toracotomía en 6 de los pacientes y por videotoracoscopia en el paciente restante.

Resultados: Tras la cirugía todos los pacientes se recuperaron completamente, sin la presencia de complicaciones postoperatorias. Un caso recidivó en 2 ocasiones, a los 33 y a los 67 meses de la resección inicial. Todos ellos están vivos en la actualidad tras un período de seguimiento medio de 19 meses (desde 1 mes a 5 años y 10 meses).

ConClusiones: El tratamiento de elección del tumor fibroso de pleura es la resección completa con seguimiento posterior, por la posibilidad de recidivas tardías de la enfermedad.

Palabras clave: Neoplasia pleural. Tumor fibroso solitario. Pleura.

\section{Introduction}

Solitary fibrous tumors account for $10 \%$ of neoplasms that arise in the pleura. ${ }^{1}$ Unlike pleural mesothelioma, in which asbestos plays an important role, solitary tumors of the pleura have not been clearly linked to a particular etiological factor. Another difference between solitary tumors and pleural mesothelioma is that most solitary tumors are benign, only $12 \%$ proving malignant. $^{2}$

Solitary fibrous tumors were once thought to arise from mesothelial pleural cells, ${ }^{3}$ but thanks to

Correspondence: Dr. W. Torre.

Departamento de Cirugía Torácica. Clínica Universitaria de Navarra.

Avda. Pío XII, 36. 31008 Pamplona. Navarra. España.

Correo electrónico:wtorre@unav.es

Manuscript received 11 November, 2003.

Accepted for publication 23 December, 2003. immunohistochemistry we now know them to be mesenchymal, with positive CD34 and vimentin expression and negative expression of cytokeratins and other epithelial antigens-a profile that is the opposite of the one seen for malignant mesothelioma. ${ }^{2}$

We describe 7 patients with solitary fibrous tumors of the pleura treated in our hospital in order to analyze the role of surgery.

\section{Case Description}

Seven patients were treated between 1997 and 2003 in a total of 9 operations. Three were women and 4 men (Table 1). Ages ranged from 25 to 63 years (mean, 52.5 years).

Three patients were asymptomatic at the time of diagnosis. The most relevant symptoms were hypoglycemia and acropachy, lower extremity edema and coughing, ipsilateral arm edema, and moderate pain on the side where the mass was located (Table 1). 


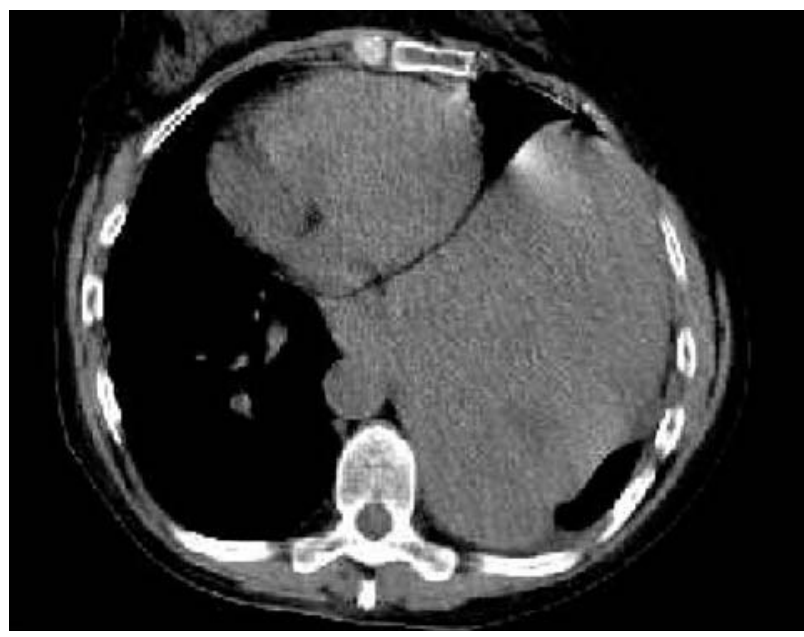

Figure 1. Computed tomography scan of the chest in which a large, heterogeneous mass with well-defined borders can be seen occupying nearly the entire left side of the thorax, displacing mediastinal structures.

All patients had computed tomography (CT) scans of the chest (Figure 1) showing a mass with well-defined borders. Pleural effusion was present in 3 cases. The lesion was biopsied before resection in 4 cases and the results were consistent with a diagnosis of localized fibrous tumor of the pleura in 3 and adenocarcinoma in 1. Mean tumor size measured at the widest point was $9.8 \mathrm{~cm}$ (range, 2.5 to $15 \mathrm{~cm}$ ).

The treatment of choice was complete surgical resection of the mass by thoracotomy in 6 cases and video-assisted thoracoscopy in 1 case (Figure 2). No complementary treatments were given (Table 1).

Histology of the excised tissue confirmed the diagnosis of localized fibrous tumor of the pleura in all cases. Cell polymorphism and a high number of mitoses in 1 patient suggested the possibility of malignant progression. The most representative results of antigen marker studies in the patients for whom they were ordered were positive vimentin and Bcl-2 expression and negative cytokeratin expression in all patients and CD34 positivity in $66 \%$ (Table 2 ).

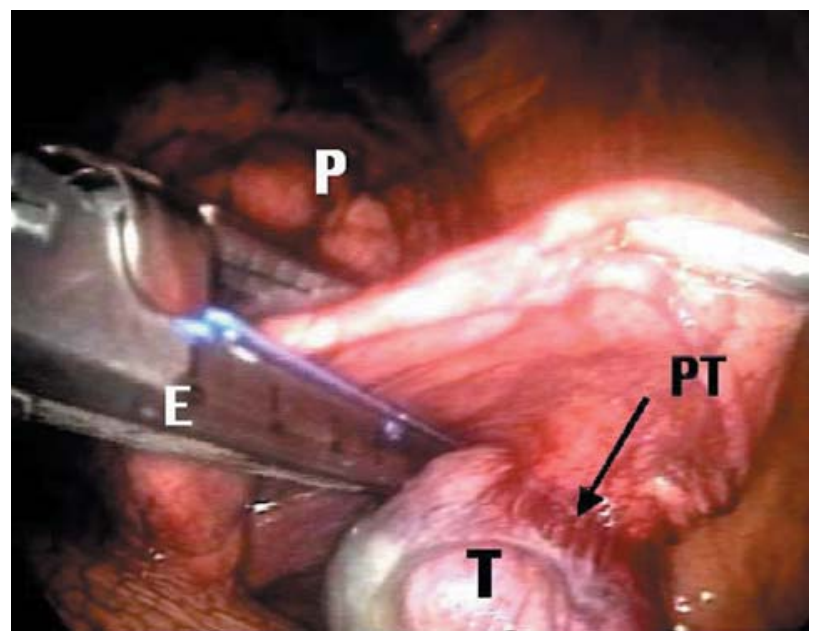

Figure 2. Videothoracoscopic view. The endostapler $(E)$ can be seen starting to section the pedicle of the tumor (PT). The arrow shows the macroscopic border between the tumor ( $T)$ and its pedicle. The lung parenchyma $(\mathrm{P})$ is located to the left of the mass.

One patient experienced recurrence even though histology suggested the tumor was benign. The first recurrence was 33 months after resection of the first tumor and the second recurrence occurred 33 months after the second tumor resection. Both recurrences were treated by surgical resection.

\section{Discussion}

Localized fibrous tumors of the pleura are fairly rare. Although they have been reported in patients as young as 5 years of age and as old as 87 years, most appear in the sixth and seventh decades of life, with fairly equal frequency in men and women. ${ }^{4}$ Clinical presentation varies and diagnosis is fortuitous in $50 \%$ of cases. ${ }^{1}$ Three of our 7 patients were asymptomatic at the time of diagnosis. Symptoms arise mainly because local spread of the mass causes coughing (33\%), chest pain

TABLE 1

Clinical Findings*

\begin{tabular}{|c|c|c|c|c|c|}
\hline Case & Sex/Age, Years & Signs/Symptoms & Computed Tomography & Size, $\mathrm{cm}$ & Biopsy \\
\hline 1 & Male/63 & Asymptomatic & $\begin{array}{l}\text { Mass, left lower quadrant } \\
\text { Microcalcifications } \\
\text { Pleural effusion }\end{array}$ & $15 \times 9 \times 8$ & Consistent with SFTP \\
\hline 2 & Female/25 & Edema, upper left arm & Mass, left upper quadrant & $13 \times 12 \times 10$ & $\begin{array}{l}\text { Consistent with SFTP } \\
\text { and benign pleural } \\
\text { tumor }\end{array}$ \\
\hline 3 & Male/63 & Asymptomatic & $\begin{array}{l}\text { Nodule, right upper lobe } \\
\text { Pleural effusion }\end{array}$ & $2.5 \times 2$ & \\
\hline 4 & Female/50 & Moderate pain, right side & Mass, right lower quadrant & $11 \times 10 \times 5,5$ & Adenocarcinoma \\
\hline 5 & Male/52 & $\begin{array}{l}\text { Edema, lower extremities; } \\
\text { cough }\end{array}$ & Mass, right lower quadrant & $7.5 \times 7 \times 3.5$ & \\
\hline 6 & Male/58 & Asymptomatic & Mass, juxtadiaphragmatic, left & 4.7 & \\
\hline
\end{tabular}

*SFTP indicates solitary fibrous tumor of the pleura. 
TORRE W, ET AL. LOCALIZED FIBROUS TUMORS OF THE PLEURA: EXPERIENCE WITH 7 RECENT CASES

TABLE 2

Interventions and Clinical Course*

\begin{tabular}{|c|c|c|c|}
\hline Case & Approach & Immunohistochemistry & Clinical Course \\
\hline 1 & Left posterolateral thoracotomy & Vimentin +, CD34 -, S100 -, LCA-, cytokeratin - & $\begin{array}{l}\text { Local recurrence, } 2.8 \text { years; } \\
\text { second local recurrence, } \\
5.6 \text { years }\end{array}$ \\
\hline 2 & Left, extended axillary thoracotomy & Vimentin,+ S100 +, CD34 -, pancytokeratin - & Asymptomatic \\
\hline 3 & Right posterolateral thoracotomy & $\mathrm{CD} 34+, \mathrm{S} 100-, \mathrm{CD} 68-$, keratin,- actin - & Asymptomatic \\
\hline 4 & Right posterolateral thoracotomy & Vimentin +, CD99 +, Bcl-2 +, CD68+, CAM $5.2-$ & Asymptomatic \\
\hline 5 & Right posterolateral thoracotomy & Vimentin,+ CD34 + & Asymptomatic \\
\hline 6 & Left video-assisted thoracoscopy & Bcl-2 +, CD34 +, cytokeratin AE3/AE1 - & Asymptomatic \\
\hline 7 & Left posterolateral thoracotomy & $\begin{array}{l}\text { Ki-67 }(10 \%), \text { CD } 34+, \text { Bcl-2 }+, \\
\text { thrombomodulin +, calretinin -, MOC } 31-\text {, } \\
\text { carcinoembryonic antigen-, TTF1 - }\end{array}$ & Asymptomatic \\
\hline
\end{tabular}

*LCA indicates leukocyte common antigen; CAM, cell adhesion molecule, TTF, thyroid transcription factor.

(23\%), breathlessness (19\%), fever (17\%), and less often hemoptysis and obstructive pneumonitis. Pleural effusion occurs in $10 \%$ of cases, ${ }^{2}$ but was seen on the CT scans of 3 of our patients. Systemic signs are less common: acropachy occurs in $10 \%$ to $20 \%, 5$ and insulin growth factor II is secreted by the tumor in $5 \%$, leading to refractory paraneoplastic hypoglycemia that disappears 3 or 4 days after surgery. ${ }^{6}$ One of our patients, who also had acropachy, debuted with loss of consciousness caused by an episode of severe hypoglycemia. Weight $\operatorname{loss}^{2}$ and galactorrhea ${ }^{1}$ are other possible signs of the tumor.

The diagnostic process remains complex. Simple radiographs will reveal an intrathoracic tumor that is round, homogeneous, solitary, and that has well-defined borders. ${ }^{4}$ Such findings are not specific to the diagnosis, however. A CT scan will reveal a lobulated mass with heterogeneity that varies according to the grade of necrosis and the presence or not of calcifications. Magnetic resonance imaging is used to establish the borders between the lesion and adjacent structures and to confirm the intrathoracic location. ${ }^{7}$ The role of positron emission tomography is currently being debated and more experience is needed before conclusions can be taken. ${ }^{8}$ The differential diagnosis is wide-ranging and complex in many cases, given that bronchogenic cysts, pulmonary abscesses, other lung and pleural neoplasms, lipomas, sarcomas, and malignant fibrous histiocytomas, among other entities, can have similar clinical and radiographic signs. ${ }^{9}$ Transthoracic CT-guided biopsy does not seem to be a reliable diagnostic method ${ }^{10}$ : given the heterogeneous distribution of cellular density within the tumor, the material obtained by this method may be insufficient. ${ }^{11}$ However, some authors consider it to be of great diagnostic value. ${ }^{12}$ In our experience, in 3 of the 4 biopsies performed, the diagnosis was congruent with the study of the excised tissue. Many authors insist that surgery is the only method for reaching a firm diagnosis through histology of the resected tissue.
One of the main concerns after diagnosing a localized fibrous pleural mass is to try to predict how it will behave. Currently, no specific test is available for achieving that goal. Traditionally, radiographic findings have been described as suggesting the tumor is benign or malignant. Likewise, cytogenetic studies have attempted to determine the alterations that are responsible for the tumor's greater or lesser capacity to invade surrounding tissue; among the markers suggested, p53 and Ki-67 have been found to be particularly important. ${ }^{13}$ The importance of differentiating between benign and malignant localized fibrous tumors lies in the difference in recurrence rates for the 2 types. Only $2 \%$ of benign tumors recur locally, ${ }^{3}$ although recurrence has been reported as long as 17 years after resection of the primary tumor. $^{6}$ Metastasis is very rare. ${ }^{3}$ However, the tumor's behavior does not always correlate with histology, given that a lesion may degenerate as time passes, to become malignant. ${ }^{4}$ In one of the cases we report, in which histology suggested that the mass would not behave aggressively, it nevertheless recurred twice. Briselli et $\mathrm{al}^{2}$ described tumor size, the presence or absence of necrosis in the excised tissue, cell polymorphism, the number of mitoses, and resectability as being useful prognostic factors, although the growth pattern may be the most important predictor, even stronger than histologic features. Egland et $\mathrm{al}^{4}$ affirmed that whether the tumor could be fully resected or not is the factor that indicates magnitude of risk. De Perrot et $\mathrm{al}^{9}$ reviewed 185 cases and proposed a system of staging based on morphologic and histologic features of the tumor, divided in 5 stages (0 to IV), each with a distinct prognosis.

The consensus is that full resection of the tumor is the treatment of choice in all cases and, if possible, with a margin of safety of 1 to $2 \mathrm{~cm}^{12}$ Adjuvant treatment with chemo- and radiotherapy is controversial, partly because experience is still limited. Chemo- and radiotherapy have been reported as prolonging survival in patients whose tumor was not fully resectable at presentation. ${ }^{15}$ De Perrot et $\mathrm{al}^{9}$ established a treatment 
algorithm based on the aforementioned 5-stage criteria, with indications that complementary treatments may be beneficial for the patient after resection of malignant and sessile tumors. Based on our experience, we have concluded that the treatment of choice for these tumors at present is surgery and that more evidence is needed before more precise conclusions can be reached regarding complementary treatments.

\section{REFERENCES}

1. Mezzetti M, Panigalli T, lo Giudice F, Cappelli R, Giuliani L, Raveglia F, et al. Surgical experience of 15 solitary benign fibrous tumor of the pleura. Crit Rev Oncol Hematol 2003;47:29-33.

2. Briselli M, Mark EJ, Dickersin GR. Solitary fibrous tumors of the pleura: eight new cases and review of 360 cases in the literature. Cancer 1981;47:2678-89.

3. Klemperer P, Rabin CB. Primary neoplasm of the pleura: a report of five cases. Arch Pathol 1931;11:385-412.

4. Egland DM, Hochholzer L, McCarthy MJ. Localized benign and malignant fibrous tumors of the pleura: a clinicopathologic review of 223 cases. Am J Surg Pathol 1989;13:640-58.

5. Okike N, Bernatz PE, Woolner LB. Localized mesothelioma of the pleura: benign and malignant variant. J Thorac Cardiovasc Surg 1978;75:363-72.
6. Luque-Sánchez F, Ruiz Zafra J, Sánchez-Palencia A, Ramos A. Hipoglucemia grave secundaria a un mesotelioma fibroso pleural recidivado. Arch Bronconeumol 1999;35:102-3.

7. de Perrot M, Kurt AM, Robert JH, Borisch B, Spiliopoulos A. Clinical behavior of solitary fibrous tumors of the pleura. Ann Thorac Surg 1999;67:1456-9.

8. Cortés J, Rodríguez J, García-Velloso MJ, Rodríguez-Espiteri N, Boan JF, Castellano JM, et al. [(18)F]-FDG PET and localized fibrous mesothelioma. Lung 2003;181:49-54.

9. de Perrot M, Fischer S, Brüdler MA, Sekine Y, Keshavjee S. Solitary fibrous tumors of the pleura. Ann Thorac Surg 2002;74: 285-93.

10. Altinok T, Topçu S, Tastepe AI, Yazici U, Çetin G. Localized fibrous tumors of the pleura: clinical and surgical evaluation. Ann Thorac Surg 2003;76:892-5.

11. Ali SZ, Hoon V, Syed H, et al. Solitary fibrous tumor. Cancer 1997;81:116-21.

12. Weynand B, Noel H, Goncette L, Noirhomme P, Collard P. Solitary fibrous tumor of the pleura. A report of five cases diagnosed by transthoracic cutting needle biopsy. Chest 1997;112:1424-8.

13. Yokoi T, Tsuzuki T, Yatabe Y, Suzuki M, Kurumaya H, Koshima T, et al. Solitary fibrous tumour: significance of p53 and CD34 immunoreactivity in its malignant transformation. Histopathology 1998;32:423-32.

14. Veronesi G, Spaggiari L, Mazzarol G, de Pas M, Leo F, Solli P, et al. Huge malignant localized fibrous tumor of the pleura. J Cardiovasc Surg 2000;41:781-4.

15. Suter M, Gebhard S, Boumghar M, Peloponisios N, Geton CY. Localized fibrous tumours of the pleura: 15 new cases and review of the literature. Eur J Cardiothorac Surg 1998;14:453-9. 